\title{
The role of the history of science
}

\section{CHARLES SINGER}

The store of scientific knowledge is a general treasure-house from which all men may draw. And yet-perhaps because of the wide spread of scientific ideas - we seldom remind ourselves that the development of the stock of scientific ideas, the heritage of all men, has always been the work of a very small band. Men capable of great scientific effort are rare and, for their effectual working, an intellectual environment is needed that is well nigh as rare as themselves. Surely the contemplation of the conditions under which such men have laboured and lived, the examination of their training and mental history, of their ways of life, and of the human setting must be of some value to those who would follow in their footsteps or prepare others to do so. Nor is the reverse side of the picture without its lesson. The study of those social, economic and philosophical conditions that fail to produce effective scientific fruits, or that yield only bizarre or deformed products, can at least explain for us certain phases in the mental history of mankind. Thus the study of the scientific mood in its historical development needs little justification.

The scientific mood is perhaps one of the irreducible elements of the human spirit and cannot be defined, but we can say that it sees especially those judgements to which - given an adequate apprehension - universal assent can be obtained. The scientific mood, in the degree to which it seeks universal assent, must demand independence of all other judgements that influence mankind-judgements, for example, based on fashion or tradition or taste or passion or class. Science is thus of all studies the most truly humane, the most truly international. The man of science may, better than others, claim for himself that he is a citizen of the world and that he speaks a language that can be understood by all who call themselves men.

Modern science, in contrast to the science of early civilization including that of Greece, records not only conclusions, but also the processes by which they have been reached. This gives hope of a permanence for the science of our age that has never before been attained. Hope of permanence lies in the wide modern distribution of active centres of scientific research, and in the existence and accessibility of countless books and journals concerned with scientific work.

The need for a historical survey following on the synthesis of science of the seventeenth century was realized by many of the most forward-looking minds of the nineteenth. Thus arose an interest in the formal presentation of the history of science. Here Georges Cuvier (1769-1832) was a pioneer, for in the early years of the nineteenth century he made several

$\dagger$ Editor's note. This first presidential address was delivered at the Annual General Meeting of the British Society for the History of Science, 4 May 1948. The text is reprinted from Bulletin of the British Society for the History of Science (1949), 1, 16-18. 
attempts at presenting aspects of the history of science. The effective suggestions came, however, from Auguste Comte (1798-1857) who in 1833 set forth a scheme for a chair in the history of science in Paris. It was not much later (1834) that Baden Powell (1796-1860) Savilian Professor of Geometry at Oxford, produced his little History of Natural Philosophy. Many parerga on somewhat similar lines were thrown off in numbers by two other mathematicians of the time, Lambert Quetelet (1796-1874) and Augustus de Morgan (1806-1871). But the pioneer of the history of science, as a subject and in the form in which we know it today, was undoubtedly William Whewell (1794-1866), the great Master of Trinity, one of the most learned men of his century. His History of the Inductive Sciences of 1837 and his Philosophy of the Inductive Sciences are of permanent value. Both are still useful and both must always find a place in any library of the history of science.

The circumstances that led to a recession of academic interest in the subject after the brilliant efforts of these men require further elucidation. During the remaining two-thirds of the nineteenth century there were many able essays in particular departments of the history of science but until the twentieth century, the great comprehensive work of Whewell remained without a rival.

The next important event in the history of the history of science is George Sarton's dedication of himself to the subject about 1912. Of all men, whether living or dead, Dr Sarton has made the most sustained attempts to master the material for the great theme of the development and product of the scientific mood throughout the ages. His work yields the necessary materials for an account of the science of classical antiquity. It contains also the first attempt at a complete and ordered summary of the extremely important oriental phase of the scientific mood when it dwelt almost wholly outside Europe. The passage of science and philosophy to the Hellenistic, Syriac and Hebrew nearer East in the early Christian centuries; the infiltration of Islam with scientific ideas, achieved by writers of Nestorian, Jewish, Pagan and Moslem affinities in the eighth, ninth and tenth centuries; the flowering of Arabic science in the eleventh and twelfth centuries and its later wilting; these processes provide Sarton's work with a grand series of chapters of the very highest interest and importance, not only to the historian of science, but also to the general historian. Nor has Sarton failed to make important investigations into the more modern records of science.

There are only two living writers on the history of science whose works can be compared to those of Dr Sarton for massive and constructive learning. Professor Thorndike has succeeded in arranging the vast inchoate mass of manuscript material that bears on the scientific mood in Western Europe until the end of the seventeenth century. In Professor Partington's magnificent treatise on the origins of chemistry we possess for the first time a searching, documented and completely marshalled survey of all that is known of the technology of the ancient Eastern civilizations.

There is meaning in the fact that these three great synthetic attempts to trace the spirit of reason have been made by men, one of whom is a product of Gallic, one of American and one of British culture. These three cultures are the main defence against the tribal disruption from which civilization has suffered repeatedly in the past and may well suffer again in the future. Against such disruption the disinterested employment of reason is in the end the only effective weapon. Only through science can man know his world. Only 
by the aid of science can man truly know either his fellows or himself. Should science cease to be international, we may know of a surety that the end of civilization is at hand. It would be as it were, the Hippocratic sign of impending death.

Activity averting such dissolution was manifested in the early twentieth century by the steps taken in 1920 by the Carnegie Institute and Harvard for the transplantation to the safer hemisphere of Dr Sarton, his work, and the international journal Isis fathered by him. Then came the foundation in the USA of the international History of Science Society. In 1927 the vision of Aldo Mieli led to the foundation of the International Academy for the History of Science, the first president of which was the already venerable Gino Loria, who in his tenth decade is happily still adding to knowledge. The Academy was fostered through good and evil days by the devotion of Aldo Mieli and of its honorary treasurer Hélène Metzger, victim of Nazi savagery. It has since formed an International Union, affiliated to the International Council of Scientific Unions, itself fostered by the yet wider orbit of the United Nations Educational Scientific, and Cultural Organization (Unesco).

This name leads once more to consideration of the role of the history of science. There is a striking analogy with that of humanism five hundred years ago. Both made small beginnings in a disturbed world. In the fifteenth century, scholastic philosophy was breaking down; the Universal Church was ceasing to be universal; economic revolution was displacing the old values based on land ownership. Politically, feudalism was dissolving into the nation states. In education, logic was yielding to the humanistic stress on language. In philosophy, theology, economics, politics, education, great discontinuities were temporarily healed by humanism. Comparable discontinuities in our world may in the next generation be comparably bridged by the evolution of a new humanism, that historical outlook which may broaden to survey the history of civilization itself. The scientific age must recognize its need to know and to understand the history of science. 